IZA DP No. 6878

Exploring the Early-life Causes and Later-life

Consequences of Migration through a Longitudinal Study on Ageing

Alan Barrett

Irene Mosca

September 2012 


\title{
Exploring the Early-life Causes and Later-life Consequences of Migration through a Longitudinal Study on Ageing
}

\author{
Alan Barrett \\ TILDA, Trinity College Dublin, \\ ESRI and IZA \\ Irene Mosca \\ TILDA, Trinity College Dublin \\ and ESRI
}

Discussion Paper No. 6878

September 2012

\author{
IZA \\ P.O. Box 7240 \\ 53072 Bonn \\ Germany \\ Phone: +49-228-3894-0 \\ Fax: +49-228-3894-180 \\ E-mail: iza@iza.org
}

\begin{abstract}
Any opinions expressed here are those of the author(s) and not those of IZA. Research published in this series may include views on policy, but the institute itself takes no institutional policy positions. The IZA research network is committed to the IZA Guiding Principles of Research Integrity.

The Institute for the Study of Labor (IZA) in Bonn is a local and virtual international research center and a place of communication between science, politics and business. IZA is an independent nonprofit organization supported by Deutsche Post Foundation. The center is associated with the University of Bonn and offers a stimulating research environment through its international network, workshops and conferences, data service, project support, research visits and doctoral program. IZA engages in (i) original and internationally competitive research in all fields of labor economics, (ii) development of policy concepts, and (iii) dissemination of research results and concepts to the interested public.
\end{abstract}

IZA Discussion Papers often represent preliminary work and are circulated to encourage discussion. Citation of such a paper should account for its provisional character. A revised version may be available directly from the author. 


\title{
ABSTRACT \\ Exploring the Early-life Causes and Later-life Consequences of Migration through a Longitudinal Study on Ageing
}

\begin{abstract}
Between 2009 and 2011, fieldwork was undertaken for the first wave of the Irish Longitudinal Study on Ageing (TILDA). Extension information was collected on about 8,500 people aged 50 and over and living in Ireland, covering topics such as economic circumstances and health. One of the features of Ireland's older population is the remarkably high proportion of returned migrants, that is, former emigrants who have returned to live in Ireland. According to the TILDA data over 20 per cent of Ireland's over 50s are returned migrants. This group represents a sub-population who is likely to have faced specific challenges over the lifecourse and who may now have specific circumstances and needs. The group also provides an opportunity to explore the impacts of migration through the generally under-utilised approach of comparing stayers and returners. In this paper, the authors report on work which has been undertaken on return migrants using the TILDA data. This work has revealed higher rates of childhood abuse victimhood among the returned migrants, higher rates of alcohol problems among some of them and higher rates of social isolation. The work can inform the design of social policy within Ireland. It can also add to the international literature on the impacts of migration over the life-course.
\end{abstract}

JEL Classification: J14, J15

Keywords: return migrants, older adults, social isolation, child abuse, alcoholism

Corresponding author:

Alan Barrett

TILDA, The Irish Longitudinal Study on Ageing

Lincoln Gate

Trinity College

Dublin 2

Ireland

E-mail: barretal@tcd.ie 


\section{Introduction}

Ireland is a country whose demography is characterised by a long experience of migration. As discussed in Barrett (2005), Ireland saw net population outflows in every decade between the 1870s and the 1960s. Although the pattern was broken in the 1970s, large-scale net outflows re-emerged in the 1980s and have done so again in the aftermath of the economic collapse of the late 2000s. Such large-scale and persistent outflows have led to the existence of an Irish diaspora, most notably in the United States and the United Kingdom but also elsewhere. However, return migration has also led to a situation in which a large number of former Irish emigrants now live in Ireland, with many of them being older people who have returned after an extended period away.

Empirical research on migration, certainly within economics, typically involves comparisons between immigrants and natives using data from receiving countries. However, the existence within Ireland of a large group of returned migrants opens up the possibility of migration-related research being conducted by comparing people of the same nationality but who differ in terms of whether they lived away or not. Examples of this approach include Barrett and O’Connell (2001) and Barrett and Goggin (2010) who examine wage differences between returned migrants and stayers. They conclude that migration represents an investment in human capital for some which is rewarded on return to the home labour market through a wage premium for returners relative to comparable people who have remained in Ireland.

In this paper, we report on a recent extension of research on migration which exploits the return and stayer groups who are resident in Ireland. Between 2009 and 2011, the first wave of Ireland's new longitudinal study on ageing (The Irish Longitudinal Study on Ageing (TILDA)) collected detailed information on over 8,500 people aged 50 and over and living in Ireland. In the TILDA sample, 24 percent of men and 21 percent of women have lived abroad for at least six months. Forty six percent of the male return migrants and 43 percent of female return migrants have lived abroad for at least ten years. Such large numbers of returned migrants mean that it is possible to uncover new insights about the causes and consequences of migration. For a country such as Ireland, with a large population of return migrants, it is important to understand the circumstances and challenges of this group across ages. However, any potential challenges facing older returned migrants are likely to be more acute because of the length of time that they may have spent away.

The paper is structured as follows. In Section 2, we provide more detail on TILDA and discuss issues such as survey content. In Section 3, we provide a brief overview of Irish migration in order to provide some context. In Sections 4, 5 and 6 we review the TILDAbased research that has been done to date on migration-related issues as they relate to Ireland's older people. In Section 4, we consider what determined emigration out of Ireland for individuals. In Section 5, we report on work that aims to investigate whether emigration led to greater psychological stress. In Section 6, our attention turns to issues that currently face Ireland's older retuned migrants. Migration, in particular long-term migration, removes people from their social networks and this was particularly the case for people who left Ireland in the 1950s and 1960s, before internet-based communications and low-cost airlines. The research which we discuss in Section 6 is concerned with establishing whether Ireland's 
older returned migrants currently suffer greater degrees of social isolation and loneliness compared to those who never lived away. Section 7 concludes.

\section{The TILDA data}

The Irish Longitudinal Study on Ageing is a dataset containing information on a nationally representative sample of over 8,000 people aged 50 and over living in Ireland. In 2009, data collection for the first wave of TILDA began and continued into 2011. At the time of writing (September 2012), the second wave of data is being collected and the expectation is that future waves of data will be collected at two year intervals. In this way, a panel dataset will be created. TILDA was designed with a number of considerations in mind but among the more important of these was a desire to achieve a high degree of comparability with the existing longitudinal studies on ageing such as the English Longitudinal Study on Ageing (ELSA), the Health and Retirement Study (HRS) in the US and the Survey of Health, Ageing and Retirement in Europe (SHARE).

In TILDA, data on participants is collected in three ways. First, a computer-aided personal interview (CAPI) is conducted, through which a range of questions are asked covering topics such as income and wealth, employment status, health status and healthcare utilisation, early life circumstances and migration history. Second, a self-completed questionnaire (SCQ) is left with respondents through which information on more sensitive topics is sought. For example, respondents are asked about the quality of their relationships, about any histories of alcohol problems and also about the incidence of abuse, both physical and sexual, in early life. The third strand of data collection is through an extensive health assessment. Two dedicated centres, in Dublin and Cork, were established whereby respondents come to these centres and undergo a variety of tests covering cognition, gait and balance, cardiovascular and optical health, and also general items such as height and weight. Blood is also taken from respondents.

The response rate for the CAPI interview in the first wave of TILDA was 62 per cent, thereby providing the sample of 8,504. Of this group, 85 per cent returned completed SCQs and 72 per cent underwent a health assessment. Of those who underwent a health assessment, 14 per cent opted for a scaled-down version which was conducted in their homes.

\section{Ireland's history of migration and the 50 pluses}

Although Ireland has experienced large population outflows since the Famine of the 1840s, we restrict this brief overview of migration to the period of relevance to those in the TILDA sample, the over 50s. In Figure 1, we show the rates of population net outflow per 1,000 of population from 1936 to the present.

\section{- Figure 1 about here -}

Someone who was born in 1920 would have turned 16 in 1936 and so would have been among the group deciding whether or not to migrate in that year. Such a person would have been aged 90 in 2010 when the TILDA data was being collected and so at the upper end of the age distribution among participants. If we continue to take 16 as an age that would be 
typical for those considering leaving, we can see that net outflows continued to 1971 and so were a feature of the economic/demographic environment facing those born up until 1955. People born in that year were aged 55 at the time of the data collection and so at the younger end of TILDA's age spectrum. In general, it is clear that most TILDA participants entered adulthood when Ireland faced population outflows. It can also be seen from Figure 1 that the rate of population outflow that faced the TILDA generation was greater than that which faced the generation who entered adulthood in the 1980s.

The decade 1951 to 1961 saw the highest rate of net outflow since the 1870s, with almost 400,000 (net) leaving. This led to the population reaching its lowest level in the twentieth century at just 2.8 million in 1961. Those aged 15-24 were the largest group in the outflow, numbering 147,000. However, even at a time of massive population haemorrhage, there was a net inflow of those aged over 65 (11,500 over the decade).

In the years 1880 to 1921, 87 per cent of Irish emigrants went to the United States and only 10 percent went to the United Kingdom. However, the Great Depression contributed to a shift in this pattern. Between the late 1940s and the early 1970s, again the period of relevance to TILDA participants, over 80 per cent of Ireland's emigrants went to the UK. As regards the education levels of those leaving, it is argued by O'Gràda and Walsh (1994) that with the low level of education in the population generally and the widespread incidence of emigration, the emigrants themselves were relatively uneducated. Work on the occupations held by Irish emigrants by Hughes and Walsh (1976) sees this reflected in the case of men, with 60 percent in the skilled, semi-skilled and unskilled socio-economic categories. However, Hughes and Walsh (1976) find a more favourable occupational distribution for Irish women in the UK.

While an amount of data is published by Ireland's Central Statistics Office on net migratory flows and on the population of non-nationals in Ireland, there is no official source on the number of returned migrants in the country. As noted in the Introduction, the TILDA data suggest that over a fifth of those aged 50 and over have lived outside of Ireland for at least six months. The data used by Barrett and Goggin (2010) show that 15 percent of those employed in Ireland in 2006 have lived outside of Ireland for a period of one year or more.

In summary, when the TILDA generation were young, they lived in an Ireland which was experiencing large population outflows. Most of them went to the UK and were relatively uneducated and unskilled, especially the men. A significant number have now returned to Ireland and so have created a large sub-population of returned migrants among Ireland's older population.

\section{Reasons for emigration uncovered by TILDA}

Most of the research on the determinants of emigration from Ireland within the economics literature has focussed, unsurprisingly, on economic issues. As reviewed by Barrett (2005), economic studies (for example, Geary and O’Gràda, 1989 and O’Gràda and Walsh, 1994) typically use the annual rate of net migration between Ireland and the UK as a dependent variable in an econometric model and then explore whether other variables explain movements in the migration flows. The explanatory variables used capture relative economic conditions in Ireland and the UK and hence include relative wages and relative rates of 
unemployment across the two jurisdictions. Most of these studies show that the size of the net flow is related to relative economic conditions.

Beyond the economics discipline, other research points to broader determinants of emigration. Leavey et al. (2004) report a desire on the part of Irish emigrants "to escape a claustrophobic and depressing existence in a rural environment that provided little chance for social intercourse or individual growth” (p. 768). Over thirty years earlier, Bovenkerk (1973) reported that motives such as a desire "to see the word" and "to see how other people live" were also present.

More recently, Delaney et al. (2011) suggest that the abuse, both physical and sexual, of young people in Ireland's reformatory schools in the middle decades of the twentieth century may have led to out-migration on the part of victims. The focus of that study is on the poor health outcomes for the Irish in the UK, with the authors providing evidence to suggest that the poor health was brought to the UK by these emigrants as opposed to their poor health developing while in the UK. They quote the Ryan Commission ${ }^{1}$ as estimating that 50 percent of those who attended the reformatory schools in the period in question emigrated. While not all of these would have been victims of sexual or physical abuse, the prevalence of abuse which was uncovered by the Commission would suggest that many were. Delaney et al. (2011) also quote a 2001 report on sexual violence in Ireland which concluded that almost a third of women and a quarter of men had been subjected to some form of sexual abuse as children.

As an initial reason for migration is likely to impact on the success or otherwise of a move, it is important to have a sense of the determinants of migration at the individual level. The TILDA data contain information on a range of early life circumstances, including socioeconomic status, health and poverty in childhood and parental education. In the SCQ, respondents are also asked to report whether, before turning 18, they were physically or sexually abused and whether their parents had drug or alcohol problems. By comparing the circumstances of returned migrants with those who did not live outside of Ireland for a prolonged period of time, we can see how the groups differed at that point in their lives. Any differences are potentially related to the original decision of the returned-migrants to emigrate out of Ireland. It should be noted that only those currently living in Ireland are observed and, as such, emigrants who remained abroad are not observed. Hence, the view on the potential determinants of migration is not complete.

Tables 1 and 2 are taken from Barrett and Mosca (2012) and show, for men and women separately, how return migrants and stayers differ in terms of early life circumstances. The focus of that paper is on patterns of alcohol dependence across return migrants and stayers and early life circumstances are used as explanatory variables. Here, we present the data again with a view to highlighting what can be learned about migration motives.

The first broad point to be made about Table 1 is that while male return migrants differ from stayers, there are important differences across return migrants themselves depending on whether they are short-term (less than ten years) or long-term (ten years or more) migrants. The parents of short-term migrants are relatively more educated than those of

\footnotetext{
${ }^{1}$ This was an official inquiry into abuse at these schools.
} 
stayers but this is not the case for long-term migrants. By contrast, long-term migrants are more likely than stayers to have grown up in poor families and in rural areas.

Striking differences also emerge when negative early life events are considered. Table 1 shows that short-term male migrants are more likely to report to have had parents with drug or alcohol problems. They are also more likely to report having been victims of physical or sexual abuse. While 9.3 percent of male stayers report having been the victim of sexual or physical abuse in childhood, the corresponding figure for short-term migrants is 15.7 percent. Hence, the suggestion of Delaney et al. (2011) is confirmed by the TILDA data for this group at least. These differences are not present when we compare stayers and long-term migrants.

In Table 2, we see that some of the patterns for men are repeated in the case of women. For example, the parents of short-term female migrants are relatively more educated compared to those of stayers. Long-term female migrants are more likely to have grown up in rural areas. As regards physical or sexual abuse, short-term female migrants are, like their male counterparts, more likely to report they have been victims. Again repeating the pattern for men, there is no difference between long-term migrants and stayers.

Summing up, while research on the determinants on emigration from Ireland has expanded beyond purely economic considerations, the TILDA data provide quantitative evidence that physical and sexual abuse may have been a contributing factor for some in the decision to leave. Older people who have been victims of abuse in childhood have a distinct set of needs and vulnerabilities. When this is combined with an experience of migration, it is likely that the needs and vulnerabilities are increased.

\section{- Tables 1 and 2 around here -}

\section{Psychic costs of migration}

Many papers in the economics literature on migration begin with the following simple behavioural model. Individuals are characterised as comparing the lifetime streams of earnings in origin and destination countries. Migration occurs (assuming no legal constraint) if the difference in the lifetime earnings streams in the country of destination and origin is greater than the costs of migration. These costs of migration are assumed to include pecuniary expenses such as travel costs but also non-pecuniary elements such as "psychic costs" (Sjaastad, 1962). This term refers to the emotional impact of leaving family and friends and having to cope with life in an unfamiliar and potentially hostile environment.

Although the psychic costs of migration have been incorporated in theoretical models since the 1960s, little evidence has been collected on these specific costs in the economics literature. However, evidence is provided in other disciplines. A number of studies in the medical and sociological literature use data from receiving countries to compare the mental health outcomes of migrants with those of the native-born population. The majority of these studies find evidence that migrants suffer higher rates of anxiety and depression and are at higher risk of psychotic disorders (Aichberger et al. 2010; Bhugra 2004; Coid et al. 2008; Odegaard 1932; Silveira et al. 1997). These findings are explained, at least to some extent, in terms of higher social adversity, migrant stress, social isolation, depression, loneliness and poor living conditions of the migrant populations. 
Similar results are found in studies focusing on the experiences of the Irish abroad in the second half of the twentieth century, especially for men. Previous research describes the Irish community in the UK as a community with high rates of depression and high levels of social deprivation and poor health (Cochrane and Bal 1989; Commander et al. 1999; Gmelch 1986 and 1987; Harrison and Carr-Hill 1992; Leavey et al. 2004; McGrath 1991; Mullen et al. 1996; Nazroo 1997; Pearson et al. 1991). A more positive picture emerges for Irish women who lived for an extended period of time in the UK. For many of these women, being in employment, economically independent and able to send remittances home was a source of pride and self-esteem (Ryan, 2004 and 2008).

The issue of the 'psychic costs of migration' can be investigated using TILDA data. The main advantage of this dataset is that it enables comparisons of mental health outcomes between Irish stayers and return migrants, rather than between Irish migrants and natives in the receiving country. Barrett and Mosca (2012) use the first wave of TILDA and employ alcohol problems as a possible indicator of psychic costs of migration. In the empirical model, the dependent variable is set equal to one if the respondent reports having been diagnosed with an alcohol or substance abuse problem at some stage in life ${ }^{2}$ and/or scores highly in the CAGE (cut-annoyed-guilty-eye) questionnaire; zero otherwise. The CAGE questionnaire is a screening test for alcohol problems and has been extensively validated for use in identifying alcoholism (Mayfield et al. 1974; Kitchens 1994) ${ }^{3}$. The explanatory variables include current socioeconomic characteristics, socioeconomic characteristics in childhood, and negative early life events.

Table 3 reports the results of the empirical model from Barrett and Mosca (2012). Marginal effects and standard errors are reported for men and women separately. Stayers constitute the reference category. Focusing first on men, the results of Table 3 show that both short-term (less than ten years) and long-term (ten years or more) migrants are more likely to suffer/have suffered from alcohol problems. The probability of suffering/having suffered from alcohol problems is 6.2 percentage points higher for short-term migrants than for stayers $(p<0.01)$. It is 3.7 percentage points higher for long-term migrants $(p<0.1)$. Given that a relatively small proportion of the male population is affected by alcohol problems, this is a substantial difference. Turning then to women, a different picture emerges. Short-term return migrants are more likely to suffer/have suffered from an alcohol problem. The marginal effect is $0.037(\mathrm{p}<0.05)$. On the contrary, long-term migrants are less likely to suffer/have suffered from an alcohol problem. The marginal effect is $-0.045(\mathrm{p}<0.01)$.

In line with the results of the sociological and medical literature, Barrett and Mosca (2012) find evidence that Irish male migrants suffer/have suffered from psychic costs of migration. The findings for women who lived away for ten years or more offer a fascinating contrast. Their lower levels of alcohol problems suggest a favourable migration experience relative to Irish women who remained in Ireland. As noted above, other studies (for example, Ryan 2004, 2008) suggest that for some Irish women of the generation in question,

\footnotetext{
${ }^{2}$ Migrants who were diagnosed before migration are excluded from the sample.

${ }^{3}$ In TILDA self-completion questionnaire, respondents are asked to state: 1 ) if they ever felt that they should cut down on drinking (cut); 2) if people have ever annoyed them by criticizing their drinking (annoyed); 3) if they ever felt bad or guilty about drinking (guilty); 4) if they have ever taken a drink first thing in the morning to steady their nerves or get rid of an hangover (eye-opener). The test score varies from a minimum of zero to a maximum of four: zero if the respondent answers no to all the fours questions, four in the opposite case.
} 
emigration allowed a level of economic independence through participation in the labour force which was not generally available to women who remained in Ireland.

\section{- Table 3 around here -}

\section{Social isolation and loneliness on return to Ireland}

The literature on the difficulties migrants face on return to their countries of birth is scarce. This relative lack of research may be based on a view that once migrants return to their home country, they blend back in and are then essentially no different to other natives in that country of origin. However, a few studies in the sociological literature document the sense of disappointment, isolation and feelings of alienation and not-belonging experienced by migrants on return to their home country (Cerase 1967, 1970 and 1974; Christou 2006; Constable 1999; Long and Oxfeld 2004).

In Ireland, the experiences of return migrants are investigated in a number of studies. The study of Gmelch (1986 and 1987) is based on interviews with 606 Irish return migrants. The author reports that 51 per cent of individuals interviewed were not satisfied with their lives back in Ireland during their first year back. This compares to 21 per cent for those who had been back for two or more years and 17 per cent for those who had been back for more than five years. McGrath (1991) investigates the experiences of 142 migrants returning to the west of Ireland and finds that the return migrants remained a separate and distinct community. Ni Laoire (2007 and 2008) collects 33 life narratives of return migrants and concludes that 'narratives of 'not quite belonging' recur[red] among return migrants' (p. 40).

In sections 4 and 5, we highlighted that TILDA data is well-suited to investigate the determinants of migration and the issue of 'psychic costs of migration'. In this section, we highlight that TILDA data is also well-suited to investigate the difficulties encountered by migrants on return to their home country, expressed here in terms of social isolation and loneliness. This is an important research question. The absence of loneliness and social isolation is seen as an important factor for good quality of life (Sinclair et al. 1990). Also, there is a positive association between social engagement and physical, cognitive and mental health outcomes, especially for older people (Conroy et al. 2010; Glass et al. 2006; Seeman et al. 2010; Sirven and Debrand 2008; Rodriguez et al. 2011). Similarly, loneliness predicts a wide variety of mental and physical health outcomes, such as depression, nursing home admission, and mortality (Conroy et al. 2010; Grenade and Boldy 2008; Hawkley et al. 2010; O’Luanaigh and Lawlor 2008).

In this section, we report the results from Barrett and Mosca (2011). The authors use the first wave of TILDA and employ two different models to investigate whether older Irish return migrants are more likely to be socially isolated. The two outcome variables are: a binary variable equal to one if the individual is (most or moderately) isolated according to the Berkman-Syme Social Network Index (Berkman and Syme 1979), zero otherwise ${ }^{4}$; and the

\footnotetext{
${ }^{4}$ This index includes four components, expressed in terms of dichotomous variables: a) one if the individual is married or cohabiting, zero otherwise; b) one if the individual has at least two children, relatives or friends she feels close to, zero otherwise; c) one if the individual attends religious services at least once per month; zero otherwise; d) one if the individual participates in any groups (such as a sports or social group or club, a voluntary association, a self-help or charitable body), zero otherwise. Each connection type is scored either zero
} 
number of children, friends or other relatives the individual feels close to. Turning to loneliness, the outcome variable employed is the loneliness score, which ranges from zero (not lonely) to ten (extremely lonely). The score is calculated using a modified version of the University of California - Los Angeles (UCLA) Loneliness Scale (Russell 1996). ${ }^{5}$ Long-term migrants are divided into two groups: long-term recent returners (ten or more years spent away and returned to Ireland in the last decade) and long-term earlier returner (ten or more years away and returned to Ireland at least eleven years prior to the interview). The other explanatory variables include current socioeconomic characteristics and socioeconomic characteristics in childhood.

Tables 4 and 5 report the results from Barrett and Mosca (2011), separately for men (Table 4) and women (Table 5). Stayers constitute the reference category. Table 4 shows that among men both long-term recent returners and long-term earlier returners are more likely to be socially isolated. The probability of being isolated is 23.6 percentage points higher for long-term recent returners $(\mathrm{p}<0.01)$ and 11.1 percentage points higher for long-term earlier returners $(p<0.01)$ than for stayers. Long-term recent returners have, on average, 2.3 fewer close ties than stayers $(\mathrm{p}<0.05)$. There are not statistically significant differences in the social participation/presence of close ties between short-term migrants and stayers. Evidence that return migrants are more likely to be lonely is not found.

Table 5 shows that female return migrants are more likely to be socially isolated. There is also an "isolation gradient", with short-term migrants being least likely to be at risk of isolation, followed by long-term earlier returners and then long-term recent returners. Compared to stayers, the probability of being isolated is 5.4 percentage points higher for short-term migrants $(\mathrm{p}<0.06), 8.9$ percentage points higher for long-term earlier returners $(\mathrm{p}<0.05)$ and 15.4 percentage points higher for long-term recent returners $(\mathrm{p}<0.05)$. However, there are not statistically significant differences in the number of close ties and the loneliness score between female stayers, short-term migrants and long-term migrants.

In summary, the results of Barrett and Mosca (2011) show that social isolation is a significant feature of the lives of Irish return migrants and that the degree of social isolation is typically stronger for individuals who spent longer away and have returned more recently. From the perspective of the individual, such isolation is clearly a cost of migration although it may not be fully appreciated when initial migration decisions are made. To the extent that this later-life social isolation resulting from migration and return is anticipated, it may help to explain patterns of migration and return. From a broader social perspective, the presence of large numbers of return migrants in a country like Ireland leads to concerns of social isolation among these people with the potential consequences for health, both physical and mental, and care needs.

or one and the four scores are summed to create four levels (0-4) of social connection or engagement: most isolated (0-1), moderately isolated (2), moderately integrated (3) and most integrated (4).

${ }^{5}$ Four negatively-worded questions and one positively-worded question are used: how often do you feel lack of companionship? How often do you feel left out? How often do you feel isolated from others? How often do you feel lonely? How often do you feel in tune with the people around you? The frequency of the outcome variable is assessed as: hardly ever or never; some of the time; or often. 
Interestingly, Barrett and Mosca (2011) also find that return migrants are not more likely to feel lonely than stayers. The authors hypothesise that return migrants might have gone through a process of adaptation over the years, have learnt to be 'self-sufficient' and/or have developed a coping mechanism. An alternative explanation is that the modified version of the UCLA Loneliness Scale is not a good measure to capture loneliness in TILDA.

\section{- Tables 4 and 5 around here -}

\section{Conclusions}

Ireland's historic pattern of outward migration, combined with much subsequent return migration, has led to a situation in which the country has a large population of returned migrants. According to the TILDA data, over 20 per cent of the population aged 50 and over fall into this category. The existence of such a group raises important social policy questions. For example, as this is a group that is relatively socially isolated, are its members in need of specific supports? The existence of this group also gives rise to the possibility of exploiting an under-utilised approach to migration research, namely, comparing people of the same nationality who live in the same country but who differ in terms of whether they once lived outside of their home country for an extended period. By using the TILDA data to exploit this research opportunity, work on Ireland's older returned migrants is emerging which can provide insights into the sorts of social policy questions mentioned above.

The work reviewed here showed that rates of childhood abuse victimhood are higher among the returned migrants compared to stayers, thereby suggesting that flight from stressful and damaging circumstances may have been a factor for some emigrants. The incidence of alcohol problems over the lifetime is higher for male migrants and for women who stayed away for less than ten years. However, for women who stayed away for more than ten years, the incidence is lower. This suggests that emigration for this one group provided psychic benefits as opposed to psychic costs. Finally, rates of social isolation are higher for returned migrants.

These results suggest that many of Ireland's older returned migrants have faced specific challenges in life and continue to do so. As later waves of the TILDA data become available, it will be possible to track how the trajectories of stayers and returners differ across issues such as physical health and depression. In this way, and from a healthcare delivery and social policy perspective, it will be possible to develop deeper insights into the needs of the returned migrants. More broadly, research on this group through the TILDA data will provide on-going contributions to the international literature on the impact of migration over the lifecourse. 


\section{References}

Aichberger, M.C., Schouler-Ocak, M., Mundt, A., et al. (2010). Depression in middleaged and older first generation migrants in Europe: results from the Survey of Health, Ageing and Retirement in Europe (SHARE). European Psychiatry 25(8), 468-475.

Barrett, A. (2005). Irish migration: characteristics, causes and consequences. In K.F. Zimmermann (Ed.), European Migration: What Do We Know? (pp. 89-112). Oxford University Press.

Barrett A., \& Goggin, J. (2010). Returning to the question of a wage premium for returning migrants. National Institute Economic Review, 213(1), 43-51.

Barrett, A., \& Mosca, I. (2011). Social isolation, loneliness and return migration: evidence from older Irish adults. IZA Discussion Paper No. 6331.

Barrett, A., \& Mosca, I. (2012). The psychic costs of migration: evidence from Irish return migrants. Journal of Population Economics, doi: 10.1007/s00148-012-0438-4.

Barrett, A., \& O’Connell, P. (2001). Is there a wage premium for returning Irish migrants?. Economic and Social Review, 32(1), 1-21.

Berkman L.F., \& Syme, S.L. (1979). Social networks, host resistance, and mortality: a nine-year follow-up study of Alameda County residents. American Journal of Epidemiology, 109, 186-204.

Bovenkerk, F. (1973). On the causes of Irish emigration. Sociologia Ruralis, 13, 263275.

Bhugra, D. (2004). Migration and mental health. Acta Psychiatrica Scandinavica, 109, 243-258.

Cerase, F.P. (1967). A study of Italian migrants returning from the U.S.A. International Migration Review, 1(3): 67-74.

Cerase, F.P. (1970). Nostalgia or disenchantment: considerations on return migration. In S.M. Tomasi \& M.H. Engel (Eds.) The Italian Experience in the US (pp. 217-239). New York: Center for Migration Studies.

Cerase, F.P. (1974). Expectations and reality: A case study of return migration from the United States to Southern Italy. International Migration Review, 26, 245-262.

Christou, A. (2006). American dreams and European nightmares: experiences and polemics of second-generation Greek-American returning migrants. Journal of Ethnic and Migration Studies, 32(5), 831-845.

Cochrane, B., \& Bal, S.S. (1989). Mental hospital admission rates of migrants to England: a comparison of 1971 and 1981. Social Psychiatry and Psychiatric Epidemiology. 24(1), 2-11.

Coid, J.W., Kirkbride, J.B., Barker, D., et al. (2008). Raised incidence rates of all psychoses among migrant groups: findings from the East London first episode psychosis study. Archives of General Psychiatry, 65(11), 1250-1258.

Commander, M.J., Odell, S., Sashidharan, S.P., \& Surtees, P.G. (1999). Psychiatric morbidity in people born in Ireland, Social Psychiatry and Psychiatric Epidemiology, 34(11), 565-569.

Conroy, R.M., Golden, J., Jeffares, I., et al. (2010). Boredom-proneness, loneliness, social engagement and depression and their association with cognitive function in older people: a population study. Psychology, Health \& Medicine, 15(4), 463-473.

Constable, N. (1999). At home but not at home: Filipina narratives of ambivalent returns. Cultural Anthropology, 14(2), 203-228.

Delaney, L., Fernihough, A., \& Smith, J. (2011). Exporting poor health: the Irish in England. RAND Working Paper WR-863.

http://www.rand.org/content/dam/rand/pubs/working_papers/2011/RAND_WR863.pdf.

Accessed 31 August 2012. 
Geary, P.T., \& O’Grada, C. (1989). Post-war migration between Ireland and the United Kimgdon: models and estimates. In I. Gordon \& A. P. Thirwall (Eds.), European Factor mobility: trends and consequences. London, McMillan.

Glass, T.A., De Leon, D.F., Bassuk, S.S., et al. (2006). Social engagement and depressive symptoms in late life: longitudinal findings. Journal of Aging and Health 18(4): 604-628.

Gmelch, G. (1986). The readjustment of return migrants in Western Ireland. In R. King (Ed.), Return Migration and Regional Economic Problems (pp. 152-170). Croom Helm: London.

Gmelch, G. (1987). Return migration to rural Ireland. In H. Buechler (Ed.) Migrants in Europe: The Role of Family, Labor and Politics (pp. 265-282). Westport: Greenwood Press.

Grenade, L., \& Boldy, D. (2008). Social isolation and loneliness among older people: issues and future challenges in community and residential settings. Australian Health Review, 32(3), 468-478.

Hawkley, L.C., Thisted, R.A., Masi, C.M., et al. (2010). Loneliness predicts increased blood pressure: 5-year cross-lagged analyses in middle-aged and older adults. Psychology and Aging, 25(1), 132-141.

Harrison, L., \& Carr-Hill, R. (1992). Alcohol and disadvantage among the Irish in Britain. Federation of Irish Societies, London.

Hughes, J.G. \& Walsh, B.M. (1976). Migration flows between Ireland, the United Kingdom and the rest of the world, 1966-71. European Demographic Information Bulletin, 7, 125-149.

Kitchens, J.M. (1994). Does this patient have an alcohol problem? Journal of American Medical Association, 272(22), 1782-1787.

Leavey, G., Sembhi, S. \& Livingston, G. (2004). Older Irish migrants living in London: identity, loss and return. Journal of Ethnic and Migration Studies, 30(4): 763-779.

Long, L. \& Oxfeld, E. (2004). Coming home: refugees, migrants and those who stayed behind. Philadelphia: University of Pennsylvania Press.

Mayfield, D., McLeod, G., Hall, P. (1974). The CAGE questionnaire: validation of a new alcoholism screening instrument. American Journal of Psychiatry, 131(10), 1121-1123.

McGrath, F. (1991). The Economic, Social and Cultural Impacts of Return Migration to Achill Island. In R. King (Ed.) Contemporary Irish Migration. Dublin: Geographical Society of Ireland.

Mullen, K., Williams, R., \& Hunt, K. (1996). Irish descent, religion, and alcohol and tobacco use. Addiction, 91(2), 243-254.

Nazroo, J. (1997). Ethnicity and Mental Health. P.S.I., London.

Ni Laoire, C. (2007). 'The 'green green grass of home'? Return migration to rural Ireland. Journal of Rural Studies, 23, 332-344.

Ni Laoire, C. (2008). Complicating host-newcomer dualisms: Irish return migrants as home-comers or newcomers?. Translocations: Migration and Social Change, 4(1): 35-50.

Odegaard, O. (1932). Emigration and insanity. Acta Psychiatrica Neurologica, 4(1), 206.

O’Grada, C., \& Walsh, B.M. (1994). The economics effects of emigration: Ireland. In B.J. Ash (Ed.), Emigrations and its effects on the sending country. Santa Monica, California: RAND.

O’ Luanaigh, C. \& Lawlor, B.A. (2008). Loneliness and the health of older people. International Journal of Geriatric Psychiatry, 23: 1213-1221.

Pearson, M., Madden, M., \& Greenslade, L. (1991). Generations of an invisible minority: the health and well-being of the Irish in Britain. Institute of Irish Studies, Liverpool. 
Rodriguez, C.J., Elkind, M.S., Clemow, L., et al. (2011). Association between social isolation and left ventricular mass. American Journal of Medicine 124(2): 164-70.

Russell, D. (1996). The UCLA Loneliness Scale (Version 3): Reliability, validity, and factor structure. Journal of Personality Assessment, 66, 20-40.

Ryan, L. (2004). Family matters: (e)migration, familial networks and Irish women in Britain. Sociological Review, 52(3), 351-370.

Ryan, L. (2008). Becoming nurses: Irish women, migration and identity through the life course. In L. Ryan \& W. Webster (Eds.), Gendering migration: masculinity, femininity and ethnicity in post-war Britain (pp. 121-135). Aldershot: Ashgate.

Sjaastad, L. (1962). The costs and returns of human migration. Journal of Political Economy, 70: 80-93.

Seeman, T., Miller-Martinez, D., Stein-Merkin, S., et al. (2010). Histories of social engagement and adult cognition in middle and late life: the Midlife in the U.S. study. The Journal of Gerentology 66B(suppl 1), 141-152.

Silveira, E., Skoog, I., Sundh, V., et al. (2002). Health and well-being among 70-yearold migrants living in Sweden - results from the $\mathrm{H} 70$ gerontological and geriatric population studies in Gotenborg. Social Psychiatry and Psychiatric Epidemiology, 37, 13-22.

Sinclair, I., Parker, R., Leat, D., et al. (1990). The Kaleidoscope of Care: a Review of Research on Welfare Provision for Elderly People. HMSO, London.

Sirven, N., \& Debrand, T. (2008). Social participation and healthy ageing: an international comparison using SHARE data. Social Science \& Medicine, 67, 2017-2026. 


\section{Figures and Tables}

Figure 1: Rates population net outflow, per 1,000 of population, 1936 to 2011

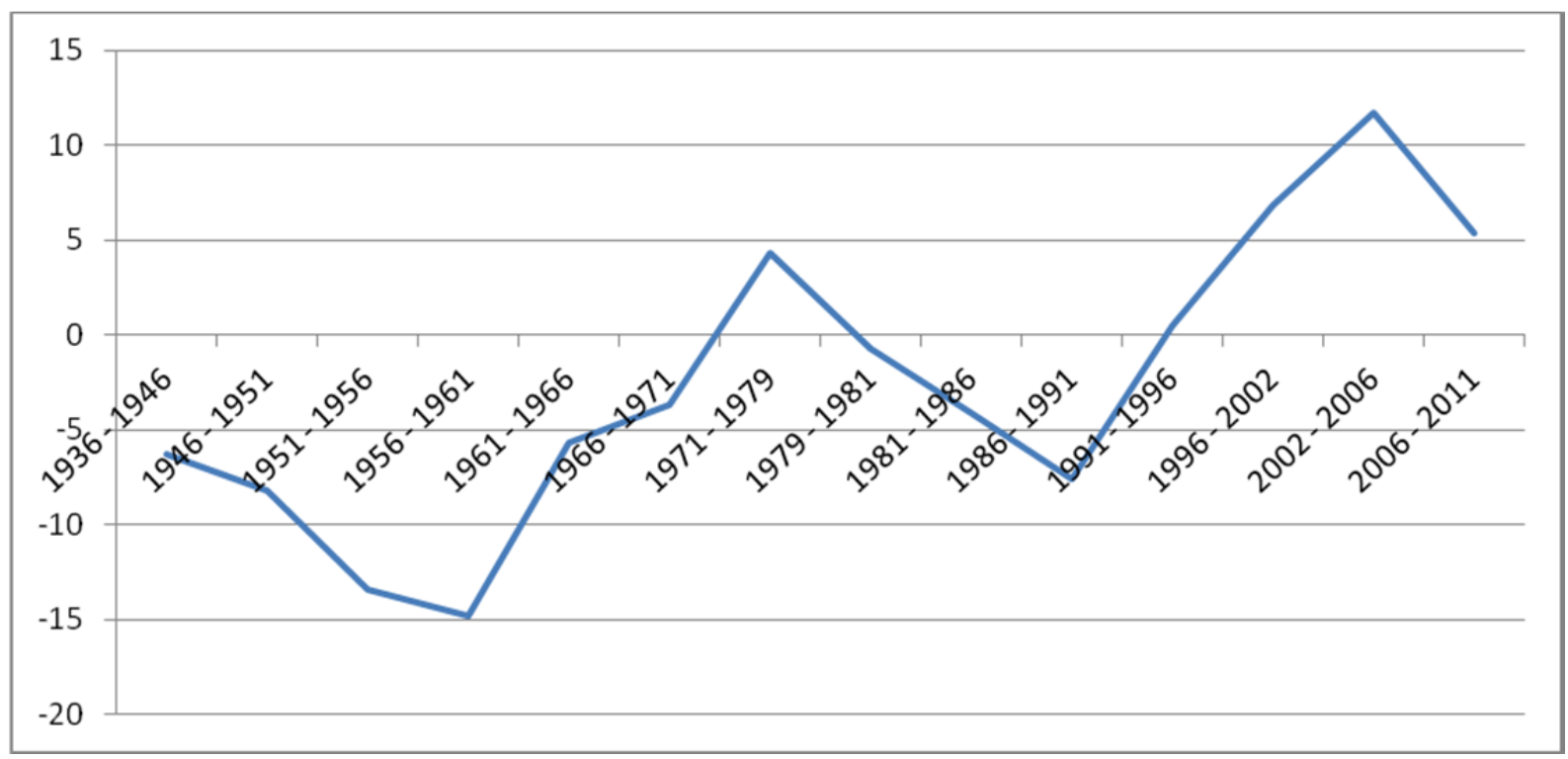

Note: Source: Central Statistics Office 
Table 1: Descriptive statistics - male stayers, short-term migrants and long-term migrants

\begin{tabular}{|c|c|c|c|c|c|c|}
\hline & \multicolumn{2}{|c|}{ Stayers } & \multicolumn{2}{|c|}{ Short-term migrants } & \multicolumn{2}{|c|}{ Long-term migrants } \\
\hline & Mean & St. Dev. & Mean & St. Dev. & Mean & St. Dev. \\
\hline \multicolumn{7}{|l|}{ Socioeconomic status in childhood: } \\
\hline Both parents have low education & 0.688 & 0.463 & $0.581^{* * *}$ & 0.494 & 0.694 & 0.462 \\
\hline $\begin{array}{l}\text { At least one parent has secondary / } \\
\text { tertiary education }\end{array}$ & 0.230 & 0.421 & $0.313^{* * *}$ & 0.464 & 0.230 & 0.422 \\
\hline Neither parent worked & 0.056 & 0.231 & 0.060 & 0.237 & 0.072 & 0.259 \\
\hline Grew up in rural area & 0.622 & 0.485 & 0.604 & 0.490 & $0.704^{* * *}$ & 0.457 \\
\hline Grew up in poor family & 0.241 & 0.428 & 0.257 & 0.438 & $0.386 * * *$ & 0.488 \\
\hline Poor health & 0.053 & 0.224 & 0.065 & 0.248 & 0.064 & 0.245 \\
\hline \multicolumn{7}{|l|}{ Negative early life events: } \\
\hline Parents had alcohol/drug problems & 0.075 & 0.263 & $0.133 * * *$ & 0.340 & 0.071 & 0.257 \\
\hline Physically or sexually abused & 0.093 & 0.290 & $0.157 * * *$ & 0.364 & 0.102 & 0.303 \\
\hline Parent(s) died & 0.141 & 0.349 & 0.132 & 0.339 & 0.128 & 0.335 \\
\hline $\mathrm{N}$ & \multicolumn{2}{|c|}{2,067} & \multicolumn{2}{|c|}{400} & \multicolumn{2}{|c|}{303} \\
\hline
\end{tabular}

Notes: Statistically significant differences between short-term migrants and stayers and long-term migrants and stayers are reported. $* * * \mathrm{p}<0.01 * * \mathrm{p}<0.05 * \mathrm{p}<0.10$.

Source: Barrett and Mosca (2012) 
Table 2: Descriptive statistics - female stayers, short-term migrants and long-term migrants

\begin{tabular}{|c|c|c|c|c|c|c|}
\hline & \multicolumn{2}{|c|}{ Stayers } & \multicolumn{2}{|c|}{ Short-term migrants } & \multicolumn{2}{|c|}{ Long-term migrants } \\
\hline & Mean & St. Dev. & Mean & St. Dev. & Mean & St. Dev. \\
\hline \multicolumn{7}{|l|}{ Socioeconomic status in childhood: } \\
\hline Both parents have low education & 0.682 & 0.466 & $0.554 * * *$ & 0.498 & 0.675 & 0.469 \\
\hline $\begin{array}{l}\text { At least one parent has secondary / } \\
\text { tertiary education }\end{array}$ & 0.222 & 0.416 & $0.339 * * *$ & 0.474 & 0.221 & 0.416 \\
\hline Neither parent worked & 0.057 & 0.232 & 0.052 & 0.223 & 0.051 & 0.220 \\
\hline Grew up in rural area & 0.641 & 0.480 & 0.641 & 0.480 & $0.741 * * *$ & 0.439 \\
\hline Grew up in poor family & 0.193 & 0.395 & 0.163 & 0.369 & 0.220 & 0.415 \\
\hline Poor health & 0.071 & 0.256 & 0.073 & 0.261 & 0.092 & 0.290 \\
\hline \multicolumn{7}{|l|}{ Negative early life events: } \\
\hline Parents had alcohol/drug problems & 0.075 & 0.263 & 0.092 & 0.289 & 0.071 & 0.258 \\
\hline Physically or sexually abused & 0.083 & 0.275 & $0.126 * * *$ & 0.332 & 0.078 & 0.268 \\
\hline Parent(s) died & 0.149 & 0.356 & 0.147 & 0.354 & 0.150 & 0.357 \\
\hline
\end{tabular}

Notes: Statistically significant differences between short-term migrants and stayers and long-term migrants and stayers are reported. $* * * \mathrm{p}<0.01 * * \mathrm{p}<0.05{ }^{*} \mathrm{p}<0.10$

Source: Barrett and Mosca (2012) 
Table 3: Results of probit model of alcohol problems, men and women

\begin{tabular}{|l|c|c|c|c|}
\hline & \multicolumn{2}{|c|}{ Men } & \multicolumn{2}{c|}{ Women } \\
\hline & Marginal Effect & Standard Error & Marginal Effect & Standard Error \\
\hline Short-term migrant & $0.062^{* * *}$ & 0.021 & $0.037^{* *}$ & 0.016 \\
\hline Long-term migrant & $0.037^{*}$ & 0.021 & $-0.045^{* * *}$ & 0.012 \\
\hline$N$ & \multicolumn{2}{|c|}{2,770} & \multicolumn{2}{c|}{3,244} \\
\hline
\end{tabular}

Notes: $* * * \mathrm{p}<0.01 * * \mathrm{p}<0.05 * \mathrm{p}<0.10$.

Alcohol problems are defined as: doctor diagnose of alcohol/substance abuse and/or high CAGE score ( $>=3$ for men and $>=2$ for women) Reference category is 'stayer'. The other explanatory variables include: age; household composition; educational attainment; current area of residence; current self-reported labour market status; smoking; parental education; socioeconomic status in childhood; health in childhood; early negative life events.

Source: Barrett and Mosca (2012) 
Table 4: Results of social isolation and loneliness models, men

\begin{tabular}{|c|c|c|c|c|c|c|}
\hline & \multicolumn{2}{|c|}{$\begin{array}{l}\text { Model 1: probit model } \\
\text { Y=1 if individual is } \\
\text { moderately/most } \\
\text { isolated according to } \\
\text { the Berkman-Syme } \\
\text { Social Network Index }\end{array}$} & \multicolumn{2}{|c|}{$\begin{array}{l}\text { Model 2: OLS model } \\
\mathrm{Y}=\text { number of close } \\
\text { children, other relatives } \\
\text { or friends }\end{array}$} & \multicolumn{2}{|c|}{$\begin{array}{l}\text { Model 3: two-limit } \\
\text { Tobit model } \\
\text { Y = loneliness score } \\
\text { (UCLA scale: } \\
\text { ranging between } 0 \\
\text { (not lonely) and } 10 \\
\text { (extremely lonely) }\end{array}$} \\
\hline & $\begin{array}{l}\text { Marginal } \\
\text { effect }\end{array}$ & $\begin{array}{l}\text { Standard } \\
\text { error }\end{array}$ & Coefficient & $\begin{array}{l}\text { Standard } \\
\text { error }\end{array}$ & $\begin{array}{l}\text { Marginal } \\
\text { effect }\end{array}$ & $\begin{array}{l}\text { Standard } \\
\text { error }\end{array}$ \\
\hline Short-term migrant & 0.044 & 0.028 & 0.154 & 0.409 & 0.144 & 0.112 \\
\hline Long-term recent returner & $0.236 * * *$ & 0.072 & $-2.301 * *$ & 0.909 & 0.098 & 0.305 \\
\hline Long-term earlier returner & $0.111^{* * *}$ & 0.035 & -0.344 & 0.501 & 0.104 & 0.134 \\
\hline $\mathrm{N}$ & \multicolumn{4}{|c|}{2,723} & \multicolumn{2}{|c|}{2,657} \\
\hline
\end{tabular}

Notes: $* * * \mathrm{p}<0.01 * * \mathrm{p}<0.05 * \mathrm{p}<0.10$.

Reference category is "stayer". The other explanatory variables include: age; educational attainment; current area of residence; current selfreported labour market status; current self-reported health; number of living children and siblings; whether mother (father) is alive; socioeconomic status in childhood; health in childhood.

Source: Barrett and Mosca (2011) 
Table 5: Results of social isolation and loneliness models, women

\begin{tabular}{|c|c|c|c|c|c|c|}
\hline & \multicolumn{2}{|c|}{$\begin{array}{l}\text { Probit model } \\
\mathrm{Y}=1 \text { if individual is } \\
\text { moderately/most } \\
\text { isolated according to } \\
\text { the Berkman-Syme } \\
\text { Social Network Index }\end{array}$} & \multicolumn{2}{|c|}{$\begin{array}{l}\text { OLS model } \\
\text { Y = number of close } \\
\text { children, other relatives } \\
\text { or friends }\end{array}$} & \multicolumn{2}{|c|}{$\begin{array}{l}\text { Model 3: two-limit } \\
\text { Tobit model } \\
\text { Y = loneliness score } \\
\text { (UCLA scale) ranging } \\
\text { between } 0 \text { (not lonely) } \\
\text { and } 10 \text { (extremely } \\
\text { lonely) }\end{array}$} \\
\hline & $\begin{array}{l}\text { Marginal } \\
\text { effect }\end{array}$ & $\begin{array}{l}\text { Standard } \\
\text { error }\end{array}$ & Coefficient & $\begin{array}{l}\text { Standard } \\
\text { error }\end{array}$ & $\begin{array}{l}\text { Marginal } \\
\text { effect }\end{array}$ & $\begin{array}{l}\text { Standard } \\
\text { error }\end{array}$ \\
\hline Short-term migrant & $0.054 *$ & 0.028 & 0.309 & 0.307 & 0.036 & 0.122 \\
\hline Long-term recent returner & $0.154 * *$ & 0.064 & 1.236 & 1.014 & -0.388 & 0.259 \\
\hline Long-term earlier returner & $0.089 * *$ & 0.037 & 0.250 & 0.498 & 0.086 & 0.144 \\
\hline $\mathrm{N}$ & \multicolumn{4}{|c|}{3,207} & \multicolumn{2}{|c|}{3,104} \\
\hline
\end{tabular}

Notes: $* * * \mathrm{p}<0.01 * * \mathrm{p}<0.05 * \mathrm{p}<0.10$

Reference category is "stayer". The other explanatory variables include: age; educational attainment; current area of residence; current selfreported labour market status; current self-reported health; number of living children and siblings; whether mother (father) is alive; socioeconomic status in childhood; health in childhood.

Source: Barrett and Mosca (2011). 